\title{
The essence of dead cattle organs in producing biogas - a sustainable solution to the energy problem in rural areas in Bangladesh and other developing countries
}

\author{
A. Jamil ${ }^{1} \&$ M. E. Jamil ${ }^{2}$ \\ ${ }^{I}$ Department of Environmental Science, Södertörns Högskola, Sweden \\ ${ }^{2}$ Daily Janata, Bangladesh
}

\begin{abstract}
In recent years, the energy crisis has become an acute problem for the whole world. Simultaneously, environmental degradation regarding energy use and sustainability has become a growing concern. In almost every country the current trend of energy use is utilizing natural resources, such as coal, gas and oil. Some developed countries practice nuclear energy and other renewable alternative energy resources. Among those renewable sources, biogas, hydro electricity, solar PVs, wind energy and tidal waves contribute the major share. Commonly, biogas is generated from biomass, wood fuel, agricultural residues, municipal waste, etc, which causes some environmental deprivation. These side effects lead scientists to look for new input materials that would be risk free. Scientists in Sweden introduced dead cattle organs as a new raw material to produce biogas. This article focuses on adopting the new raw materials for under developed countries, their availability and potentiality in sustainable development. Bangladesh has been focused on in this article as the role model of an under developed country. After thorough examination of some statistical data, this paper recommends that dead cattle organs are available in Bangladesh and at the same time discusses sustainable development utilizing this new resource. Other developing and developed countries that have high livestock populations can also utilize this prolific resource for sustainable development.
\end{abstract}

Keywords: alternative energy, availability, Bangladesh, biogas, cattle organs, energy sector, raw material, sustainable development. 


\section{Introduction}

A study has been conducted to assess the possibilities of introducing and adopting dead cattle organs as the raw material to generate biogas at the household level in rural areas of Bangladesh. Parallelly, the current energy situation in the rural areas in Bangladesh is highlighted. Biomass fuel comprises the main source of energy for the rural people. The major share of energy use is consumed for cooking and household lighting. An enormous amount of labor is spent on gathering and collecting fuel wood, agricultural residues and animal excreta, which reduces productivity among women and young children. The pressure on rural forests for fuel wood is increasing, which is leading to environmental degradation. Agricultural lands are losing vital nutrients as people are using crop residues and animal excreta for energy [1].

Bangladesh is a small country having a total of 65 per cent arable land [2], which is not sufficient to meet the internal demand for food. As a result it is not possible for Bangladesh to engage these lands for cultivating energy crops. Under the present condition, the possibilities of adopting the Swedish technology of producing biogas from dead cattle organs is considered and may be part of a solution to this problem in terms of availability of the raw material and sustainable development of rural areas.

\section{Methodology and results}

Data used in this article are collected from reliable official sources, such as international development organizations, Bangladesh official statistical departments etc. These data have acceptance to all audiences. Moreover, those official statistical data used in this article form the groundwork of this article. Statistical data has been collected from the FAO Yearbook 2005, Bangladesh Ministry of Fisheries and Livestock world bank report and some other reliable sources. These data has been analyzed using SPSS 16.0.0 statistic software. A t test has been done using those continuous data. A linear regression curve has been drawn using the SPSS software to show that the livestock population is increasing every year. Other statistical data regarding livestock slaughtering and the production of meat is also collected to prove that the amount of dead cattle organs is increasing simultaneously. The research adopted the quantitative approach with the deductive method. This article successfully shows that there is plenty of livestock available in Bangladesh and the number is increasing day by day.

This research paper might be beneficial to the Energy Ministry and other organizations engaged in the power sector in Bangladesh or in other developing countries. The NGOs that promote biogas in developing countries might find the article constructive. Foreign organizations showing interest in development programs in those countries could also find the report useful. This report is prepared based on secondary data, however, the use of primary data with a field survey could make the study more prolific. 


\section{Motivation behind biogas and dead cattle organs}

Energy is one of the key determinants of socio-economic development of any country. Bangladesh, a developing country in the third world, would require a gigantic amount of energy for development. However, Bangladesh faces a monumental challenge in the energy sector. These challenges include a very limited choice of energy sources, shortage of funds for research, technical expertise etc. These challenges are more enhanced by the pressures put on decision makers by various lobbies, an alleged lack of transparency in the decision making process and shortage of technical expertise [3].

Natural gas is the prime indigenous source of energy in Bangladesh; however the reserve is not adequate for long term internal needs. The rural energy sector, which is the largest single component of Bangladesh energy, has never received sufficient attention. Only $4 \%$ of people are connected to a gas-pipelined network in the cities and in the rural areas there is no gas network at all [4]. Only about $30 \%$ of households have access to electricity in the whole country. Only $10 \%$ of rural households have an electricity connection compared to the whole country.

Bangladesh has a small reservoir of coal, gas and oil. Commercial energy consumption is largely dependent on natural gas. About $69 \%$ of total commercial energy is produced from gas and the rest is produced from oil and a tiny portion from hydropower and coal. Per capita commercial energy consumption in Bangladesh is almost the lowest in the world [5]. The fuel consumption of per year capita per year is only $57-\mathrm{kg}$ oil equivalent. Approximately $65 \%$ of the total fuel is used for domestic purposes, $20 \%$ for small industrial purposes and $9 \%$ for non-energy use [6].

There are many areas in the country where electricity will not reach in the next 30 years. Moreover, the price of oil is too high for the rural poor people and consequently biofuel and biomass is the main source of energy use in the villages. Almost $90 \%$ of this biofuel comes from the agricultural sector [1]. About, $65.2 \%$ of biomass energy for fuel use comes from crop residues (jute sticks, rice straw, rice hulls, sugarcane refuses and other waste products), $24 \%$ from firewood twigs and leaves, $7.8 \%$ from animal excreta and dung and the rest from other resources [7].

Biogas could be a solution to the energy problem in rural Bangladesh and dead cattle organs could be used as the raw material in place of biomass. Meat is the main source of protein for the Bangladeshi people and every day a large number of animals are slaughtered to meet the internal needs for meat. The skin, bones and horns are used for other purposes, but the end products such as fats, guts and other internal organs are usually thrown away as waste.

Scientists in Sweden are producing biogas from dead cow organs such as fats, guts and other organs [8]. The technology of gas generation is the same as using other raw materials and the existing gas digesters could be used. Under this scenario, the Swedish technology is suitable from the perspective of Bangladesh in terms of availability of raw materials and sustainability. 


\section{Sustainability}

This article thoroughly follows the sustainability concept, which has become a very important concept for environment and development issues. Sustainability could be defined as the best utilization of the human and natural environment both in the present and for the indefinite future. Sustainability deals with the continuity of environmental, social, economic and ecological issues and also includes the non-human environment. In short, sustainability is a way of utilizing resources as well as reserving bio diversity and the natural ecosystems and planning to keep these ideals harmonic for a very long period. The term sustainability highlights three fundamental components of sustainable development, namely the environment, the society and economy, respectively [9].

\subsection{Ecological sustainability}

Bangladesh is a small country having very limited land for agricultural use. In fact only $65 \%$ of the total landscape belongs to arable land and only $56 \%$ of this arable land has been irrigated; the remaining 44\% has not yet been irrigated [2]. Bangladesh cultivates food crops in these arable lands; however, the amount is too little to produce enough for the internal needs. So it is not possible for the country to grow fuel wood in arable lands. The wood fuel that is used for energy comes from village trees and crop residues [4].

Crop residues are returned to the soil, they decompose and the decomposed product, humus, maintains soil nutrition, soil porosity, water infiltration and soil erosion. These crop residues are collected and burnt, consequently agricultural land is losing these nutrients. In the villages trees are being cut for fuel wood. As a result energy has become one of the main reasons for deforestation, which is leading to global warming, the greenhouse effect, climate change and rising sea levels.

The main ecological problem in using wood fuel or agricultural products is loss of biodiversity. Biodiversity refers to the number of different kinds of plants and animals that are found in a particular area [11]. Deforestation is one of the main reasons for loss of biodiversity in Bangladesh [1].

Cattle organs in the field of bio energy could prevent Bangladesh from degrading its ecology. The country does not have to change any land use pattern so there is no chance of losing biodiversity. The crop residues and animal dung and excreta could be spared to used in the agricultural lands rather than being burnt. Besides, slaughtered cattle organs, which are a waste product, usually remain in open places and rot and pollute the environment, due to lack of a good waste management system in Bangladesh. So, using of these organs could be complemented as a recycling process and the end product in biogas digesters could be used as fertilizer in the fields. It is naturally concluded that the country could save its environment and utilize those waste cattle organs to bring out the maximum output. 


\subsection{Social sustainability}

Health problems in Bangladesh are a core social problem, which has a direct link with energy use. Sometimes the shortage of domestic energy use is directly responsible in the case of food preparation. For instance, sometimes, because of a shortage of fuel in villages, people are unable to cook meat properly [4].

Biogas could be a solution to these health problems associated with cooking. In particular, this gas is more combustible. As a result biogas cooks faster and requires less time and energy.

Use of traditional sources of fuel, mainly in the open hearth stoves or clay ovens, is extremely inefficient and responsible for adverse health effects. The combustion efficiency of such stoves is low. Excessive smoke inhalation from indoor air pollution leads to serious heart, lung and respiratory infections [12].

Biogas technology enhances a positive contribution to social life and systems by improving living standard by making improvements in health care and family planning. A large number of villagers are deprived of proper health care due to the lack of electricity in remote areas. Biogas could be used to supply electricity to rural clinics for lighting and vaccine refrigeration. Besides, electrification helps family planning activities.

Moreover, some major findings of a recent USAID study's assessment about the impact of the rural electrification program in Bangladesh are: $93 \%$ of the electrified households reported a decrease in fuel cost; 78.2\% reported an increase in working hours; $62 \%$ reported an increase in household income; $81 \%$ reported an increase in reading habits; $93.7 \%$ reported an increase in children's study time; $92 \%$ reported an increase in amusement as well as standard of living; $94.7 \%$ reported an improvement in security [1].

\subsection{Economic sustainability}

The use of dead cattle organs as the raw materials to generate biogas is more economically viable than using traditional plant based raw materials. First of all, cow organs might be collected without any cost at the very beginning of the implementation of this technology. Usually, cow organs, such as guts, fats etc, are thrown away as waste. Villagers can easily collect those organs from the butchers, free of cost.

Secondly, frequent use of animal organs can lead people to think about trading of these organs. Like fuel wood, cow organs could be sold in the markets. This can lead Bangladesh to opening up a new market and that would be responsible for creating some new businesses among localities. In addition, some new fields of local jobs could be created. The regular collection of cow organs from the butchers could be a type of job. Moreover, local people could be more interested in setting up more and more ranches, which will create more local jobs.

Females can utilize the time that they could save from collecting fuel wood for income generating activities, such as poultry or homestead gardening etc, which could help them become economically strong and solvent.

Biogas technology can play a vital role in an integrated farming system, which means poly/cultures, completed by livestock, fish breeding and the waste 
recycling process. Biogas provides " $5 \mathrm{~F}$ " fuel; fertilizer; feed-staff; feedstock and food to this system [13]. Digester slurries could be used as a very good fertilizer for plant nutrition and feed staff for livestock fish. The main components of integrated biogas farming are agricultural fields, algae ponds, fish and duck ponds and animals.

Biogas can bring an economic revolution among rural people through an integrated farming system. This may help the poor dwellers get rid of malnutrition, food problems, health problems, environmental problems and above all financial problems.

\section{Current energy situation in Bangladesh}

In this study we have tried to assess the energy sector in Bangladesh. There seem to be too many actors engaged in the sector and some have dual functionality that contradicts their own interests [3]. In addition, these institutes cannot function properly due to the presence of very weak legal, regulatory and enforcement frameworks with a lack of proper manpower, funds and technical expertise.

In spite of having several policy initiatives, reports and drafts, Bangladesh lacks a clear energy strategy [3]. A number of reasons could be identified for this problem. Among those problems the mains are recurring shortages of fuel previously predicted by various sources, frequent power failures, uncertainty in the gas sector, the high cost of imported coal and liquid fuel, no significant progress in the rural energy sector, the occasional clamor for nuclear power and a shortage of renewable energy sources.

Bangladesh started gas extraction for the first time in 1955 [14,15] and today natural gas is regarded the most indigenous source of commercial fuel. Almost $70 \%$ of natural gas production is used for electricity generation. Bangladesh has a reservoir of natural gas; however, the amount is not adequate for long-term use. The most reliable accepted source states that there is 10.6 TCF (Trillion Cubic Feet) of reserved gas and 6.38 TCF as the cumulative consumption in addressing the supply issues [16], a proven probable reserve ranging from 15.4 TCF to 28.4 TCF for field development and 19 to $87 \mathrm{TCF}$ in undiscovered resources for exploration. At present Bangladesh spends about \$203 million importing about 1.708 million tons of crude oil from abroad [6]. Coal has been discovered in several places in Bangladesh and the estimated reserve is said to be 2.7 billion tones with a mine able reserve of 1400 million tones [17]. However, international assistance is needed to utilize those mines.

\section{Alternative renewable energy sources}

In 2000, the Government of Bangladesh (GOB) took a keen interest in finalizing and declaring a renewable energy policy. It was proposed that until the Energy Regulatory Commission is formed under the energy reform act, Power Cell would be responsible for carrying out all kinds of development works in this 
regard [15]. However, energy source options for Bangladesh are very limited and efforts in utilizing modern renewable resources are at a very early stage.

There have been several researches on the possibilities of other renewable alternative energy sources for Bangladesh. According to those researches, Bangladesh has some alternative energy sources such as solar, photovoltaic, wind energy, hydropower, tidal energy, wave energy, biogas, etc. Among those, biogas and hydroenergy currently exist in Bangladesh.

In 2003, Chowdhury [16] solely reflected the possibilities of photovoltaic as a renewable energy source. Salequzzaman [17], in 2000, described the possibilities of tidal energy for Bangladesh. SWERA [18], in 2001, tried to assess the possibilities of wind and solar energy as renewable energies. However, Chowdhury concluded that the country receives 5.05 to $8.76 \mathrm{kWH}$ (Kilowatt Hours) from solar radiation, which is positive, but commercial photovoltaic generation would be too expensive for Bangladesh. Salequzzaman and SWERA also declared the possibilities of using tidal energy and wind energy as inappropriate for Bangladesh.

Ocean waves present a considerable renewable energy source. Energy could be produced at any site at competitive prices with an average wave power level of over $15 \mathrm{KW}$ per meter [10]. However, for the Bay of Bengal this value is about 8 $\mathrm{KW}$ per meter. As a result, wave power is also not a viable option. A study conducted in 2001 by CWET India showed that the wind energy resource in Bangladesh is not prolific enough for grid connected wind parks, as it is less than 7 $\mathrm{m} / \mathrm{s}$ [10]. Currently, Bangladesh has a hydroelectric power plant with the capacity of $230 \mathrm{MW}$ electricity production. The GOB also has two bigger project plans.

\section{Biogas and its uses in Bangladesh}

Biogas is produced by bacteria in the bio-degradation process of organic materials under anaerobic conditions. Methanogens (methane producing bacteria) are the last in a chain of microorganisms that degrade organic material and return the decomposition matters to the environment. In this process, biogas is generated, a source of renewable energy [19,20]. Any organic biodegradable material can be digested and used as a raw material to generate biogas.

Swedish scientists have successfully used the following process to generate gas. To convert the raw materials into methane, intestines and other unused organs are shredded into slurry, pasteurized at $158^{\circ} \mathrm{F}$ for at least an hour, and placed in a sealed, oxygen-free digester. For 25 to 30 days the slurry is continuously stirred, kept at a balmy $95^{\circ} \mathrm{F}$, and gradually digested by bacteria. The stirring separates the methane from the organic sludge, and the heat keeps the bacteria lively and productive [21]).

In Bangladesh there are about 3.6 million biogas digesters installed. The digester construction materials are available and cheap. Moreover, small micro credits are available for the purchase and installation of biogas digesters for household use. In Bangladesh, biogas is usually used for cooking, household lighting, TV and cassette players. Biogas is also used for some other purposes 
throughout the world (e.g., the generation of electricity, running light machines and transportation of vehicles).

Additionally, biogas could play an important role in small industries. For instance, this gas could be used for heating purposes in poultry farms and in incubators. Methane, a component of biogas, could be used in food industries, where cleanliness is an important issue.

Electricity produced from biogas is convenient and economic for lighting rather than the direct use of biogas for the same purpose [4]. Electricity generated by biogas could be used to run refrigerators to keep medicines and injections frozen or cold.

\section{Availability of dead cattle organs and a comparison with traditionally used raw materials in terms of availability}

Existing statistical data represents that cattle organs should be available throughout the country. Bangladesh is an agro-based country where most of the agricultural works are still dependant on animal power. In rural Bangladesh most of the families raise livestock, which are regarded as a ready source of cash. These livestock provide power for cropping, transport, threshing and oilseed crushing. According to the Department of Livestock Services of the Ministry of Fisheries and Livestock, Bangladesh, the livestock population in Bangladesh is as shown in Table 1.

Table 1: $\quad$ Livestock population in Bangladesh [22].

\begin{tabular}{|c|c|c|c|c|c|c|c|}
\hline \multirow{2}{*}{$\begin{array}{c}\text { Species } \\
\text { (million) }\end{array}$} & $2000 / 01$ & $2001 / 02$ & $2002 / 03$ & $2003 / 04$ & $2004 / 05$ & $2005 / 06$ & $2006 / 07$ \\
\hline Cattle & 22.39 & 22.46 & 22.58 & 22.60 & 22.67 & 22.80 & 22.87 \\
\hline Buffalo & 0.92 & 0.97 & 1.01 & 1.06 & 1.11 & 1.16 & 1.21 \\
\hline Goat & 16.27 & 16.96 & 17.69 & 18.41 & 19.16 & 19.94 & 20.75 \\
\hline Sheep & 2.11 & 2.10 & 2.29 & 2.38 & 2.47 & 2.57 & 2.68 \\
\hline Total & 40.69 & 41.59 & 42.52 & 43.45 & 44.41 & 46.47 & 47.51 \\
\hline
\end{tabular}

Meat and fish are the main source of animal protein in Bangladesh [1]. However, many fish species are becoming scarce and therefore expensive. As a result, a large number of animals are slaughtered throughout the whole country for its internal needs. Though Bangladesh is enriched with such a huge number of livestock, the quantity of slaughtered animals is not sufficient for the demand of meat. This results in the importing of cows, goats and buffalo from neighboring countries. Every year Bangladesh imports a large number of cattle from India and most of them are slaughtered for meat.

As an Islamic country, people in Bangladesh sacrifice about 10 million cows, goats and buffaloes on a single festive day. More than 4 million cattle enter Bangladesh both in legal and illegal ways to be sold during the Eid Ul Azha festival. According to the FAO Yearbook [23], in 2002 the number of livestock imported from outside had the value of about 73.5 million US dollars [23]. In 
addition, a large number of livestock also enters Bangladesh that does not have any trace in official documents.

Fuel wood, agricultural residues and animal dung and excreta are used as the raw materials to generate biogas in Bangladesh. However, these materials are not available everywhere in the country. In addition, fuel wood is becoming more expensive because of scarcity. Agricultural residues are hard to collect due to high competition of gathering. Animal excreta and dung is hard to transport. Use of these materials is more costly and requires a high degree of labor.

Total fuel wood consumption of the country is about 8 million cubic meters per year [25]. Among those, about 5.1 million cubic meters is used for cooking purposes. It is commonly thought that the reserve forests are the main source of wood fuel supply in the country, though statistics show that $84 \%$ of total consumption is supplied from village forests. At present there is an acute shortage of fuel wood in Bangladesh. Moreover, the country does not have scientific planned cultivation of energy plantations. As a result there is always a gap between demand and supply for wood fuel. As wood is starting to acquire a monetary value, because of its scarcity, people are started to rely on biomass fuels [26].

A study conducted by FMP in 1993 had projected the estimated demand and supply of fuel wood in Bangladesh up to 2013 in terms of the current amount of available forestland. The report suggested that in 2013 the gap would be of 3811000 cubic meters [25].

\section{Conclusion}

In order to prevent and avoid the energy problems in rural areas of Bangladesh, an alternative energy source is a must. Dead cattle organs used to produce biogas could be the ultimate solution to this problem, which could imprint its footsteps as a regular source of environmentally friendly clean source of cheaper energy. It could develop the civic society and social system in the rural areas by putting in contributions to education, the health system, entertainment and division of labor. In addition, it could help improve the economic situation of rural areas by opening up new markets and creating new job opportunities. Moreover, this raw material will also help to maintain the ecological balance in equilibrium.

\section{References}

[1] Jamil, Adnan "Biogas and Cattle Organs - An Alternative Significant Source of Energy for Sustainable Development in Rural Bangladesh" Master's Thesis, Department of Life Science, Sodertorns Hogskola, Stockholm, Sweden, 2008.

[2] FAO Yearbook 2004.

[3] BEN, "Energy Strategy for Bangladesh: A Brief Survey with Recommendations", Prepared by The Energy Panel of Bangladesh Environmental Network, Bangladesh, September 2006. 
[4] Rahman, A. A., "Biogas Energy- An Alternative Solution for Sustainable Energy in Rural Areas of Bangladesh", Masters Thesis, Department of Environmental Science, Lund University, Sweden, 2000.

[5] Islam Rafiqul, "Vital Statistics: Oil, Natural Gas and Energy in Bangladesh", published by Drillbits and Tailings, USA, May 2000.

[6] World Bank, "World Development Report 2000/2001: Attacking Poverty, Selected World Development Indicators, Energy Use and Emission". New York: Oxford University Press, 2001.

[7] FAO Yearbook, 1986

[8] http://news.bbc.co.uk/1/hi/sci/tech/4373440.stm (September 11, 2006)

[9] Brundtland Report, UNCED, 1987.

[10] I. Mazharul, "Assessment of Renewable Energy Resources of Bangladesh". Version 1, May 1, 2002.

[11] Carl, J. Weinberg \& Robert, H. Williams, "Energy from the Sun", Scientific American, September 1990.

[12] M. Ezzati and D.M. Kammen, "Household Energy, Indoor Air Pollution, and Health in Developing Countries", Annual Review of Energy and Environment Vol. 27: 233-270, November 2002.

[13] Chen, G. Q., Liu, K. X. and Chen, M. (1983). In "Proc. 2nd EC Conf. on energy from Biomass", Berlin, 1982 (A Strub, P. Chartier, and G. Schleser, eds,), pp. 1072-1084. Applied Sciences, Publication, Barking, Essex, UK.

[14] Jean-Luc Dubois, “ Monitoring Urban Poverty at The Bangladesh Bureau of Statistics: Design and Implementation Issues for an Adaptive 1-2-3 Survey".

[15] Bangladesh bureau of statistics, 1992, "Statistical pocket Book of Bangladesh”, ISBN - 984-508-0, Dhaka.

[16] Penn Well, "Oil and Gas Journal”, 2005.

[17] Energy and Mineral Resources Division, Ministry of Power, Energy and Mineral Resources; Government of the People's Republic of Bangladesh. December 1, 2005. "Draft Bangladesh Coal Policy".

[18] BEPP, Ministry of Planning, Govt. of Bangladesh, Dhaka, 1990. "Bangladesh Energy Planning Project, Final report". Vol. 1-4.

[19] [19] S. Chowdhury, "Photovolatics as a Renewable Energy technology in Bangladesh and its Potential for Increasing Welfare, Gender Equity and Environmental Sustainability", PH. D Thesis, University of Maryland at College park, USA, May 2003.

[20] Salequzzaman M. Newman P., Ellery M. and Corry B. (2000), "Prospects of Electricity in Coastal Region of Bangladesh: Tidal Power as a Case Study", Journal of Bangladesh, Vol. 2, No. 1, June 2000 .

[21] Global Environmental facility, Project Document of "Solar and wind Energy Resources Assessment (SWERA)”, May 2001.

[22] Nyns, E: J. (1986) Biomass, Micro Organisms for Special Applications, Microbial Products I, Energy from Renewable Resources, 
in vol. 3 / ed. By H.J. Rehm and G. Reed, - Weinheim; Federal Republic of Germany: VCH.

[23] Nyns, E: J. (1986) Biomithanation Process in vol. 8 / ed. By H. J. Rehm and G. Reed. Microbial Degradations- Weinheim; Federal Republic of Germany: VCH.

[24] http://www.popularmechanics.com/technology/industry/2390906.html?pa ge $=2$ (July 26, 2006)

[25] http://www.dls.gov.bd/about_us.htm (January 06, 2009)

[26] FAO Yearbook Livestock Bā̄ladesh, 2005a

[27] Farid Uddin Ahmed and Miyan Rukunuddin Ahmed, "Woodfuel Production Supply in Bangladesh", Wood Energy news, Vol. 15 No. 1, June 2000.

[28] Singoro, A. K., "Biogas as an Alternative Energy Source in Uganda", report from a minor field study, ISBN 91-576-3360-6, Uppsala, 1988. 